\title{
Aristotle's concept of energeia in Autumn Journal by Louis MacNeice, poet, classics scholar and intellectual
}

\section{Mélanie White}

\section{(2) OpenEdition \\ Journals}

Electronic version

URL: http://journals.openedition.org/etudesirlandaises/1629

DOI: 10.4000/etudesirlandaises. 1629

ISSN: 2259-8863

Publisher

Presses universitaires de Rennes

Printed version

Date of publication: 30 September 2009

Number of pages: $55-69$

ISBN: 978-2-7535-0982-5

ISSN: 0183-973X

Electronic reference

Mélanie White, "Aristotle's concept of energeia in Autumn Journal by Louis MacNeice, poet, classics scholar and intellectual », Études irlandaises [Online], 34.2 | 2009, Online since 30 June 2011,

connection on 20 April 2019. URL : http://journals.openedition.org/etudesirlandaises/1629; DOI :

10.4000/etudesirlandaises.1629

This text was automatically generated on 20 April 2019.

(C) Presses universitaires de Rennes 


\title{
Aristotle's concept of energeia in Autumn Journal by Louis MacNeice, poet, classics scholar and intellectual
}

\author{
Mélanie White
}

1 As a classics scholar, a Thirties poet, and later a teacher of Greek at the university of Birmingham, MacNeice was involved in different types of intellectual circles. While his public-school education at Marlborough School and subsequent degree from Merton College Oxford render him the archetype of the perfect scholar, one finds at the core of MacNeice's poetic career a tension between a feeling of belonging to the upper-class and an even stronger need to connect with the rest of society, what he called "the ordinary people". This great awareness of class distinctions is turned against himself in many ironical and even scornful comments he makes about his own upbringing, and more specifically about his classical training. In canto XIII of Autumn Journal, MacNeice remains ironically sceptical about the proclaimed greatness of the education he received: "I ought to be glad / That I studied the classics at Marlborough and Merton". His lack of enthusiasm becomes a criticism of the class-oriented nature of a classical education:

We learned that a gentleman never misplaces his accents,

[...]

That the boy on the Modern Side is merely a parasite

But the classical student is bred to the purple, his training in syntax

Is also a training in thought

And even in morals; if called to the bar or the barracks

He always will do what he ought ${ }^{1}$.

In this ironical portrait of the classics scholar as an exemplary member of society with a strong sense of duty and high morals, a well-mannered "gentleman" is also an intellectual: "And I got my honours degree / And was stamped as a person of intelligence and culture". In such a static view of society, the intellectual is defined by MacNeice not only by his "intelligence and culture" but by his inability to connect with reality and the contemporary life which surrounds him. A comment made by MacNeice in his 
autobiography after moving to Birmingham to take up a teaching position, at the beginning of the 1930s, thus expresses this lack of connection and its resulting uselessness:

Living in Birmingham had reconciled me to ordinary people; I found reassurance in silent gardeners, inefficient hospital nurses, in a golfer cupping a match in his hands in the wind, in business men talking shop in the train. I found no such reassurance in the intelligentsia. I remembered how under the Roman Empire intellectuals spent their time practising rhetoric although they would never use it for any practical purpose; they swam gracefully around in rhetoric like fish in an aquarium tank. And our intellectuals also seemed to be living in tanks ${ }^{3}$.

MacNeice thus criticizes the intellectuals of his time for distancing themselves from life, secure in the unreachable safety of an aquarium, looking out but not putting into practical use their knowledge and abilities. The opposite and more meaningful role of the intellectual, according to MacNeice, is political involvement, a social role embodied by the Thirties poets' interest in Communism:

But there was an important exception - the group of poets who had appeared in New Signatures, published in 1931. They were all politically Left [...]. The strongest appeal of the Communist Party was that it demanded sacrifice; you had to sink your ego. At the moment there seemed to be a confusion between the state and the community, and I myself was repelled by the idolisation of the state [...].

I had a certain hankering to sink my ego, but was repelled by the priggishness of the Comrades [...]. I joined them however in their hatred of the status quo, I wanted to smash the aquarium ${ }^{4}$.

MacNeice is situated on the verge of both possible alternative roles of the intellectual. While he wanted on the one hand to "smash the aquarium" and break the separation between intellectuals and real life within society, he always refused to take a strong political stance and remained at a distance from the other Thirties poets in that matter. MacNeice's own understanding of the role of the intellectual seemed to stem from his reading of Greek philosophers more than from political involvement. Despite the sometimes ironical and off-hand manner with which he recalled his classical training, and the criticism he made of the class distinctions attached to such a scholarly education, MacNeice built his own intellectual posture on the grounds of his knowledge and understanding of Greek culture, more specifically on the definition of the real and the actual inherited from Aristotle's Metaphysics, and on the role model of the Greek poet of the $5^{\text {th }}$ century B.C. Thanks to Aristotelian concepts, MacNeice was able to define his place and role as intellectual, poet, and man within society.

MacNeice's direct relationship with the historical moment of his times is transcribed in its very immediacy thanks to the form of the journal, as in Autumn Journal, published in 1939. He explores diverse illustrations of Aristotle's concept of energeia, a notion which puts forward the primary role of movement, both motion and activity, in the belief that the only complete reality is actuality. MacNeice's interest in Aristotle's concept of actualization through motion as an end in itself also influences his representation of man as a participant in an organic community. Aristotle's definition of man as a "political animal" is linked in MacNeice's works to the status of the Greek poet of the $5^{\text {th }}$ century B.C. Still, MacNeice considers man's essential nature as distinct from his being part of a community, a collective form with shifting margins and conflicting values. Man's essential existence is indeed illustrated in Autumn Journal, following Aristotle's Poetics, as "man-in-action", and he is included in the overall motion of the actual. We shall see how, through his reading of Aristotle's concept of energeia in the Metaphysics, MacNeice refines 
throughout Autumn Journal a perception of the present tense, first of all as perpetual motion and secondly as a representation of the actual as distinct from the real. Finally, we will see how MacNeice, following Aristotelian concepts, defines the essential role of man within a community and as man-in-action.

\section{The present as perpetual motion}

6 MacNeice's refusal to adhere to any specific political creed does not entail a removal from the contemporary life of his times. On the contrary, the entrenchment of his poetry in the present moment is both a concern for everyday living and a necessity to record through very minute and detailed sensations the concrete passing of time. The form of the journal that he chose for his two long poems, Autumn Journal (1939) and Autumn Sequel (1953), written during particularly tense historical periods, testifies to his need to record, and report, on a day-to-day basis events that make reality, as he explains in his preface to Autumn Journal:

In a journal or a personal letter a man writes what he feels at the moment; [...] I was writing it from August 1938 until the New Year and have not altered any passages relating to public events in the time of what happened after the time of writing ${ }^{5}$.

7 It is therefore striking that in these two journals MacNeice makes a recurring use of references to Greek philosophers and historians, while he is first and foremost recalling the present as he is experiencing it. MacNeice's scholarly knowledge of Greek philosophy is thus anything but remote and static, or distanced from any practical purpose. On the contrary, MacNeice's understanding of Aristotle's distinction between energeia and kinesis takes the form of a work in progress throughout Autumn Journal. This notion enables him to place movement at the centre of his representation of reality, and to make the present a transitory stage, but also to create a shifting sense of time as a constant and perpetually re-activated and re-actualized process. MacNeice thus tried to understand Aristotle's separation between energeia and kinesis:

Aristotle the biologist was anxious to avoid the gulf between Being and Becoming established by Plato the mathematician. His concept of energeia - significant and so, in a sense, eternal movement exemplified in the time world - was an antidote to the static and self-contained heaven of Plato's transcendent Forms. But when you look into him you find he does not go far enough: reality, rescued from the One, is traced back to the infima species but not the individual unit, while his distinction between energeia (significant and absolute movement) and kinesis (movement which is merely relative) restores the Platonic gulf that he has just been trying to fill in. Or so I thought. Aristotle allows that what is energeia from one angle may be kinesis from another; but in that case, I thought, kinesis also should be a permanent principle, whereas Aristotle supposes a highest grade in which mind thinks only itself and this he exempts from kinesis ${ }^{6}$.

MacNeice's tentative distinction reappears in a different form in many parts of Autumn Journal. Firstly, his rephrasing of Aristotle's energeia as "eternal movement exemplified in the time world" and "significant and absolute movement" gives to this notion a temporal value which forms the basis of his representation of the present moment as motion. In several instances, energeia as movement seems to exemplify a self-contained, in-between time zone which exists out of duration or chronology, halfway between a complete, but ultimately impossible, forgetfulness of the past and visions of a future of action. In Canto III, the repetition of movement exemplifies Aristotle's notion of the purity of action in energeia: 
But the final cure is not in his past-dissecting fingers

But in a future of action, the will and fist

of those who abjure the luxury of self-pity

And prefer to risk a movement without being sure

If movement would be better or worse in a hundred

Years or a thousand when their heart is pure ${ }^{7}$.

In these lines MacNeice envisions first of all a future of action and then transfers this image onto the plane of sheer movement. Autumn Journal was written on the eve of the Second World War and throughout this long poem MacNeice expresses the need for action - "For they say that now it is time unequivocally to act" - as fear and panic pervaded Europe. The immediate movement which seems to replace potential action is usually juxtaposed with other temporalities, thus severing it from mere chronology. In the lines quoted above the fixed past and the uncertain future no longer form a reliable temporal frame since movement annihilates duration, making a hundred years the same as a thousand. In other parts of Autumn Journal, memory and history appear as an ordered past whose stasis literally blocks the movement of the present moment: "That was then and now is now / Here again on a passing visit, / Passing through but how / Memory blocks the passage". The emphasis on "now" is even more explicit in passages where MacNeice puts on the same level the arbitrary creation of a chronology inherent in any historical format and the freedom represented by pure movement. Movement, in its perpetually renewed rhythm, becomes the only present tense, usually associated to an ING verb form:

And still the acquiring of unrelated facts,

A string of military dates for history,

$[\ldots]$

And still the exhilarating rhythm of free

Movement swimming or serving at tennis ${ }^{10}$.

10 The rhythm based on the anaphoric repetition of "and", characteristic of the whole of Autumn Journal, is broken by "movement", which stands out as something more meaningful than the accumulation of historical and cultural landmarks - facts, dates, and random knowledge. Similarly, the repetition of "still", meaning both persistence and immobility, reinforces the idea of a repetitive movement frozen in its very actualization. In the in-between state of energeia, movement as process does not produce anything beyond itself but is complete in its actualization. In the Metaphysics, Aristotle places motion as the source of his distinction between the potential and the actual:

The distinction of potentiality and actualization exists in each class of things, and motion is the actualization of the potential as such [...]. Motion takes place when the actualization itself exists, and neither before or after. Thus the actualization of that which is potentially, when it exists actually, not as itself but as movable, is motion. [...] Motion, then, is the actualization of the potential qua potential. That motion is what we have defined as being, and exists only when the actualization itself exists, is clear ${ }^{11}$.

11 In canto XX of Autumn Journal, which recalls a visit to the National Gallery in London, MacNeice uses a pictorial metaphor to represent such a movement. If the scenes represented in the still lifes of the museum are motionless due to the very nature of their material, MacNeice can still decipher the potential movement at the source of their creation as they represent the endless repetition of time:

And the still life proclaiming with aplomb

The self-content of bread or fruit or vases

[...] 
The sea of the past glimmers with white horses,

A paradigm

Of life's successions, treacheries, recessions;

[...]

And history has refuted them and yet

They cast their shadows on us like aspersions;

Propellers and white horses,

Movement, movement, can we never forget

The movements of the past which should be dead ${ }^{12}$ ?

The fact that these paintings convey movement contradicts the immobility of a chronologically distant past. The motions, frozen as they are in the process of their actualization in the still lifes, partake of a temporal structure suspended over traditional chronology where the past is dead and only the present is alive. In the last question, the ability to forget the past, which is the sine qua none condition to live in the present, is in fact made impossible by the omnipresence of movement. Movement becomes the only reality the poet is able to grasp. MacNeice thus creates a temporality based on sheer movement, on a never-achieved process which defies the linearity of past and present, in a time frame where duration has no value. In the lines quoted above, MacNeice distinguishes the past in the still lifes, represented as a dynamic stage thanks to its inherent movement ("the sea of the past", "the movements of the past") and history, which elaborates a selection: "history has refuted them". The scenes on these paintings are "refuted" by history, it would seem, because they are forever frozen in the state of energeia, unable to achieve entelechia, a completeness which would qualify as history.

\section{The actual and the real}

Indeed, the overall centrality of the process rather than its resulting product reinforces

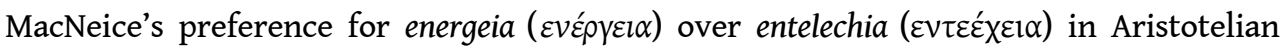
terms. In his commentary on the original text of the Metaphysics, W. D. Ross throws light on this distinction and its relation to kinesis:

[...] it appears that strictly speaking $\varepsilon v \varepsilon \varepsilon_{p} \varepsilon \varepsilon \alpha$ means activity or actualization, while $\varepsilon v \tau \varepsilon \lambda \varepsilon \dot{x} \varepsilon 1 \alpha$ means the resulting actuality or perfection. Yet $\varepsilon v \varepsilon \dot{\varepsilon} \rho \varepsilon \varepsilon \alpha$ is not a movement towards something more than itself; this is the difference between it and kívnor ${ }^{13}$.

14 By focusing on the process, MacNeice builds his journal on the representation of the "actual" as distinct from the "real" in Aristotelian terms. In book $\Theta\left[\begin{array}{c}{\left[{ }_{0}\right.} \\ 0\end{array}\right.$ Aristotle gives the following definition of "actuality": "The word 'actuality', which we connect with 'complete reality', refers originally to movement: hence we do not ascribe movement to non-existent things, though we assign to them predicates like 'thinkable' because they will sometime actually exist ${ }^{14 "}$.

MacNeice keeps the link between actuality and movement in order to apprehend the contemporary only through actual motion. In canto XIV, where MacNeice recalls his classical education, he puts forward Aristotle's distinction between the real and the actual:

And it made one confident to think that nothing

Really was what it seemed under the sun,

That the actual was not the real and the real was not with us

And all that mattered was the One ${ }^{15}$. 
16

he calls "the actual" shapes the main material of Autumn Journal, as he strives to convey the suspension of time in the process of its actualisation. Such a representation of the present was criticized in 1941 by a reviewer for being "too topical, too transitory, too reportorial ${ }^{16 "}$. Similar criticisms were made about MacNeice's second long poetic journal, Autumn Sequel, and he thought these comments stemmed from a misunderstanding of the basic nature of such an undertaking: “... one very long poem, Autumn Sequel, the point of which was missed by most of the book-reviewers, was "occasional" but not casual, being an attempt to marry myth to "actuality"17". MacNeice's choice of the term "actuality" to explain the value of the transitory nature of Autumn Sequel underlines the value he ascribes to such a concept. The distinction MacNeice makes between "occasional" and "casual" similarly emphasizes that "actuality" is, according to him, the core of the contemporary, its true pattern. By focusing on energeia rather than entelechia, MacNeice aims at reproducing the transitory nature of the real. If energeia is indeed a process with shifting characteristics, it is valuable in its authenticity and truth as it allows the poet to record the permanent principle of movement as he is himself creating his own poetic work, in a time zone which suspends chronology.

fluidity with which classical references are woven into daily meditations throughou Autumn Journal is apparent in the way MacNeice mixes two different notions based on movement to deal with the contemporary, as he confronts the centrality of flux in Heraclitus' philosophy with Aristotle's energeia. By using these two concepts for two distinct temporalities, MacNeice elaborates a time frame for the present moment. What distinguishes these two concepts is the opposition between the constant change in the flux and the perpetual repetition of the same in energeia. This difference enables MacNeice to draw the line between "reality" and "actuality". While at university, MacNeice recognised the flux as reality ("Heraclitus recognised the flux - and one has to do that to be modern ${ }^{18 ")}$, adding:

[...] we were pathetically eager to be realist (which meant the mimesis of flux), but we always fell back upon Form. This paradox came out in our admiration for contemporary novelists - Joyce, D. H. Lawrence, Virginia Woolf - who give you the flux but serve it on golden platters. [...] The flux is reality, so has to be recognised, but you can make this recognition with style ${ }^{19}$.

MacNeice pinpoints here his appreciation, as a poet, of the flux in the contemporary novels of his time. He also underlines the difficult balance to be achieved in poetry between realism as mimesis and the constraints of the poem, what he calls "Form" and "style". The realism MacNeice linked to the use of the flux by the contemporary novelists of his time becomes a concern for actuality more than reality in his poetry. It seems that for MacNeice, while flux is the necessary metaphor for real mimesis in modern novels, poetry requires a different pattern. In Autumn Journal, energeia entails a vertical representation of time where the process, and its repetition, never reach the state of entelechia, and thus never enter the chronological and linear representation of history as progress and advance. What is striking in Autumn Journal is the coexistence of detailed time markers (as, for instance, in canto XII: “This is Tuesday / The $25^{\text {th }}$ of October, $1938^{20}$ ") which accurately situate the time of writing of each canto within a larger chronological order, the cyclical return of the seasons that give a rhythm to the poem as a whole (as it begins in Canto I with "Close and slow, summer is ending in Hampshire ${ }^{21}$ "), and the representation of history as an arbitrary line of events which form the background to the present in motion, exemplified in the suspension of duration in energeia. The juxtaposition of these different time scales triggers the visualisation of several embedded 
strata of reality, where the actual occupies the foreground. The flux is kept by MacNeice only in relation to history, and it exemplifies the poet's difficulty to accept the linear progression of time between past and present, a traditional historical representation he refuses in order to place the present as the only "actual" temporality. Hence, the image of the "stream of history" used in canto XIV ${ }^{22}$ reappears in canto XV with the image of the river representing both constant flux and the impossibility of repetition it entails:

You can't step into the same river twice so there can't be

Ghosts; thank God that rivers always flow.

Sufficient to the moment is the moment;

Past and future merely don't make sense

And yet I thought I had seen them...

But how, if there is only a present tense ${ }^{23}$ ?

These lines illustrate MacNeice's contrary use of the flux, to represent the linear passing of time, and energeia, to focus on the actual as a vertical moment in time suspended over chronology. While the flux is a metaphor, energeia is a matrix that enables MacNeice to rethink the present. The idea of a present "tense" is particularly interesting as it makes of the present not only a time frame, but a verbal, and thus active, stage akin to a process. Similarly, MacNeice represents the past as a no longer active verbal form, but on the contrary as a Latin form of the verb used as an adjective in order to express a fixed form of achievement, both final and past: "But life began to narrow to what was done - The dominant gerundive $e^{24}$ ". The "dominant gerundive" of the past is opposed here to the permanent movement of the "present tense". As a moment embedded in a permanent state of energeia, the present is in constant motion but also a perpetual repetition of the same. Throughout Autumn Journal, the growing fear of the possibility of a Second World War is felt through a sense of the present as a return of the past. If the ghosts of the past cannot step in the same river twice within the flux metaphor, they can indeed reappear in the re-actualization of energeia. Hence, in Autumn Journal, the present, staged as a minimal time unit where repetition prevails, is often a re-actualization of events that have already happened - "it has all happened before,/Just like this before ${ }^{25 ",}$ which focuses on the fear of a new war:

And so to my flat with the trees outside the window

And the dahlia shapes of the lights on Primrose Hill

Whose summit once was used for a gun emplacement

And very likely will

Be used that way again ${ }^{26}$.

MacNeice's concern with the actual thus creates a specific temporality which allows his poetic journal to fit the uncertainty of his day and the fearful contemplation of the future, with the growing tension spreading through Europe, as well as the past, with the remaining images of the First World War, threatening because they might repeat themselves.

\section{The poet as man-of-action}

21 It comes as no surprise that it is also through references to Aristotle that MacNeice defines the status of man and poet within society in such troubled times. It seems that MacNeice, at least when he wrote Autumn Journal, defined his own role in comparison with, firstly, the intellectuals and fellow Thirties poets of his time, secondly, the role of the Greek poet of the 5th century B.C. which he found exemplary, and thirdly, the 
Aristotelian definition of essential man as man-in-action. MacNeice's refusal to take part in any political movement did not reduce the necessity he felt to be a representative of the community, and hence to take up the political role of man in Aristotelian terms. The statement he makes in The Strings are False about the way the New Signatures poets, all politically Left, merged the concepts of state and community, shows how he himself perceived these two notions as distinct, and how he was ready to abolish his ego to be a representative of the community, but not of the state. The distinction between community and state made by MacNeice does not make his insertion within such a community easier. Indeed, his emphasis on man's need to take part in a human community is a source of uncertainty throughout Autumn Journal, since the poet's persona seems unable to define a community he could relate to and represent. In Modern Poetry, MacNeice states what is for him the role of the poet, inspired by that of the Greek poet:

The poet is primarily a spokesman, making statements or incantations on behalf of himself or others - usually for both, for it is difficult to speak for oneself without speaking for others or to speak for others without speaking for oneself. [...] his [the Greek poet of the $5^{\text {th }}$ century B.C.] attitude as poet was not distinguished from his attitude as man, which naturally resulted in much of his poetry being didactic or moralizing. [...] It was assumed that life was the source and subject of poetry. And life for the Greeks meant life within a community ${ }^{27}$.

The didactic nature of Greek poetry in the 5th century B.C. recalls MacNeice's own statement in his prefatory note to Autumn Journal, where he underlines the mediating value of his poem, "something half-way between the lyric and the didactic poem ${ }^{28 "}$. Such didacticism is clear in the following lines of canto XII: "All that I would like to be is human, having a share / In a civilised, articulate and well-adjusted / Community where the mind is given its due ${ }^{29 "}$, again not distinguishing the role of man and that of poet. The $5^{\text {th }}$ century-B.C. poet in Greece is a model for MacNeice because he is the archetype of Aristotle's "political man". But the community of the Greek poet, framed within the polis, is not to be found in MacNeice's times. A community for MacNeice is human rather than national, the latter being a source of inner conflict and uncertainties. MacNeice questions the possible achievement of Aristotle's political role for man within his own time and society. The possibility of his own ability to take up such a role is open to debate in Autumn Journal, as James Matthew Wilson explains in his analysis of MacNeice's use of Aristotelian ethics in the poem:

\footnotetext{
It is by no means an exclusively Aristotelian poem, but it does at least present the Greek philosopher as more than an object of a bankrupt nostalgia for "The Glory that was Greece". Aristotle's role in the poem, in fact, is [...] a foundational figure for an alternative to philosophical modernity. Late in the poem, MacNeice complains of the recalcitrance of his own modern conscience to accept the Aristotelian political nature of man. The emphasis that conscience places on the individual as "self-supporting" rather than socially constituted, MacNeice calls "Eternal self-abuse $\mathrm{e}^{30}$.
}

Wilson here refers to canto XVII where MacNeice, in the traditional opposition between Plato and Aristotle he says he inherited from his public-school education ${ }^{31}$, explores the notions of Alter Ego and the metaphorical representation of man as an organism in its necessary interaction with a community of other men:

And Aristotle was right to posit the Alter Ego

But wrong to make it only a halfway house:

Who could expect - or want - to be spiritually self-supporting,

Eternal self-abuse?

Why not admit that other people are always 
Organic to the self, that a monologue

Is the death of language and that a single lion

Is less himself, or alive, than a dog and another $\operatorname{dog}^{32}$ ?

The needed interaction of man with others is transferred onto the plane of poetry where a monologue is considered to be a sterile mode, while on the contrary the poet is encouraged to be open to dialogue, a notion MacNeice goes back to in Modern Poetry when he states that "A poet should always be 'collaborating' with his public ${ }^{33}$ ". MacNeice does indeed stage a dialogue with Greek philosophers, as well as with a larger community of readers, though the nature of this community is difficult to define. It seems that MacNeice wants to address mankind in general, and not a specific national community, be it England or Ireland. He represents the latter in canto XVI in particularly hard stereotypical traits and thus destroys the possibility of a coherent and supportive community in his native country. It seems more natural and easy for MacNeice to forge a dialogue with Greek philosophers than with what he senses is a fake image of Ireland: "It is self-deception of course:/There is no immunity in this island either ${ }^{34 "}$. MacNeice refuses on the one hand to be part of the national community of an Ireland whose values he mostly rejects, while on the other he likewise avoids being assimilated to the poetic generation of the Thirties by, for instance, refusing its political involvement. In the following lines, the conflicting nature at the core of MacNeice's identity explains the uncertain value attached to community as an unreal form of collective belonging:

Such was my country and I thought I was well

Out of it, educated and domiciled in England,

Though yet her name keeps ringing like a bell

In an under-water belfry.

Why do we like being Irish? Partly because

It gives us a hold on the sentimental English

As members of a world that never was ${ }^{35}$.

The creativity of man's collective role versus the sterility of his self-contained individual ego is redefined by MacNeice not only through the idea of community, which remains problematic, but thanks to Aristotle's definition of the essence of man through action. Using again the form of a debate with the expression "Aristotle was right", MacNeice continues in canto XVII his dialogue with the Greek philosopher to define the role of man:

Aristotle was right to think of man-in-action

As the essential and really existent man

And man means men in action; try and confine your

Self to yourself if you can ${ }^{36}$.

MacNeice here extends his first perception of the role of man as political man, that is to say within a community, to the need for collective action. The essence and existence of man depends on the one hand on his ability to interact with others but also on his constant activity. Just as the present can only be perceived through the motion of the actual, man only really exists when in action, in a state of actualization close to energeia. For him, man's essential being is actualized only in action, that is to say when he is creating something out of himself, or moved into action by an outside force. The constant interaction of man with other people seems to be an extrapolation on Aristotle's notion of organic unity ("other people are always organic to the self"), which MacNeice transfers here onto a community of people, where the acting and the acted upon, agent and patient, are merged. Aristotle defines potential action thus:

In a sense the potency of acting is one with that of being acted on; in a sense it is different. The one is in the patient (it is because even the matter is a motive 
principle that things can be acted on, different things by different things); the other is in the agent. Thus so far as a thing is an organic unity it cannot be acted on by itself, for it contains no distinction of agent and patient ${ }^{37}$. motion and action actualize the essence of the real and of man. Thanks to Aristotelian concepts, MacNeice elaborates a staging of the present tense on a temporal and visual plane where an in-depth historical perspective is an inert frame, not a meaningful scale. In Autumn Journal, the contemporary is a vertical representation of time as process, based on the motion of energeia, where the actual is the present as it is performed. Even if the recording of the actual can be deemed too transitory, it questions the intrinsic nature of the real and the role of the poet, qua intellectual, within his society and time. Freezing the present moment in the perpetual motion and repetition of energeia elaborates a temporality where poetry, in its own actuality, stages the actual as the real.

\section{NOTES}

1. Collected Poems of Louis MacNeice, E. R. Dodds (ed.), London, Faber, 1979, p. 125-26.

2. Ibid., p. 126.

3. Louis MacNeice, The Strings are False: An Unfinished Biography, London, Faber, 1965, p. 145.

4. Ibid., p. 145-46.

5. Louis MacNeice, Collected Poems, p. 101.

6. Louis MacNeice, The Strings are False, p. 125-126.

7. Louis MacNeice, Collected Poems, p. 106.

8. Ibid., p. 124. 
9. Ibid., p. 116.

10. Ibid., p. 120.

11. Aristotle, Metaphysics, a revised text with introduction and commentary by W. D. Ross, vol. 2, Oxford, Clarendon Press, 1924, K. 8. 1065 b 5-32, p. 325.

12. Louis MacNeice, Collected Poems, p. 141-42.

13. Aristotle, Metaphysics, $\Theta$. 2. $1046 \mathrm{~b}$ 30, p. 245.

14. Ibid., p. 243.

15. Louis MacNeice, Collected Poems, p. 126.

16. Introduction to Louis MacNeice and his influence, Kathleen Devine and Alan J. Peacock (eds.), Gerrards Cross, Colin Smythe, 1998, p. 10.

17. Selected Literary Criticism of Louis MacNeice, Alan Heuser (ed.), Oxford, Clarendon Press, 1987, p. 211.

18. Louis MacNeice, The Strings are False, p. 109.

19. Ibid., p. 118-119.

20. Louis MacNeice, Collected Poems, p. 124.

21. Ibid., p. 101.

22. Ibid., p. 128.

23. Ibid., p. 131.

24. Ibid., p. 120.

25. Ibid., p. 108.

26. Ibid., p. 109.

27. Louis MacNeice, Modern Poetry, A Personal Essay, $2^{\text {nd }}$ ed., Oxford, Clarendon Press, 1968, p. 1-2.

28. Louis MacNeice, Collected Poems, p. 101.

29. Ibid., p. 125.

30. James Matthew Wilson, “Louis MacNeice's Struggle with Aristotelian Ethics”, New Hibernia Review 10:4, p. 65.

31. "The stress laid upon Ancient Philosophy in our course repeated the pattern of our social position as public-school boys; we spent a great deal of time pitting Aristotle against Plato but had not adequate foil to the school of idealism which both represent." (Louis MacNeice, The Strings are False, p. 125.)

32. Louis MacNeice, Collected Poems, p. 135.

33. Louis MacNeice, Modern Poetry, p. 196.

34. Louis MacNeice, Collected Poems, op. cit., p. 133.

35. Ibid., p. 132.

36. Ibid., p. 136.

37. Aristotle, Metaphysics, 媐. 1. 1046a 19, p. 240.

38. Aristotle, Poetics, edited and translated by Stephen Halliwell, new ed., Cambridge, Mass. , Harvard University Press, 1995, chapter 6, 49b 36, p. 49.

39. Ibid., chapter 6, 50a 15, p. 51. 


\section{ABSTRACTS}

Drawing extensively on Aristotle's Metaphysics and Poetics, this article argues that Louis MacNeice's training in classical literature and philosophy may have helped him to devise an original theory of time, one in which the present is not posited as mediating between the past and the future, but has a value of its own, deriving from Aristotle's concept of energeia as motion. Refuting some of the criticism that has been levelled at Autumn Journal and Autumn Sequel, his two long poems, this article also distinguishes between literature as "actuality" and literature as mere "reportage", and shows that for MacNeice, the need for action in times of crisis, did not preclude the necessity to reconsider the role of the poet as man-of-action. The intellectual positioning that this reconsideration entails brings to light MacNeice's simultaneous rejection of nationalism and communism as the only alternative left to man on the eve of World War II.

À partir d'une relecture serrée de la Métaphysique et de la Poétique d'Aristote, cet article entend démontrer que les études de Louis MacNeice dans le domaine de la littérature et de la philosophie de l'Antiquité lui ont sans doute permis d'élaborer une conception du temps originale, dans laquelle le présent n'est pas un simple point de relais entre le passé et le futur, mais a une valeur intrinsèque, qui s'inspire du concept aristotélicien d'energeia comme mouvement. Prenant le contre-pied de certaines critiques qui ont été formulées au sujet de Autumn Journal et Autumn Sequel, les deux poèmes longs de MacNeice, cet article établit également une distinction entre une vision de la littérature comme "actualisation » et une vision de la littérature comme simple « reportage ». Ceci montre que pour MacNeice, la nécessité d'agir dans des moments de crise historique, ne doit pas détourner d'une réflexion sur la fonction du poète comme homme d'action. Le positionnement intellectuel induit par cette réflexion met en lumière certaines des raisons qui ont conduit MacNeice à rejeter le nationalisme et le communisme comme la seule alternative s'offrant à l'individu au seuil de la Seconde Guerre mondiale.

\section{INDEX}

Keywords: Aristotle, writer as critic, social role of the artist, MacNeice Louis, intellectuals, philosophy

Mots-clés: Aristote, écrivain comme critique, rôle social de l'artiste, intellectuels, philosophie

\section{AUTHOR}

\section{MÉLANIE WHITE}

Université de Metz 